\title{
Potential for Natural Gas to Act as a Substitute Fuel in China
}

Unlike coal and oil, natural gas does not have an exclusive niche. Analysis of international experiences has found that growth in natural gas consumption in other countries has come about largely as a result of substituting gas for other fuels. It is only substituted for other fuels when its price is competitive compared to other energy sources, incentivising users to adopt it. The competitive forces that drive such changes derive from users' desire to have their requirements for energy services met while reducing their energy source costs to a minimum.

This section therefore examines the price of natural gas that would make it competitive in different application sectors, relative to the currently preferred fuel used in that sector.

The primary application sectors for natural gas are power generation, transport and shipping, urban gas, industrial fuel and natural gas chemical engineering. In the power generation sector, natural gas competes primarily with coal. In the transport and shipping industry, it primarily competes with diesel. In the urban fuels gas sector, competition in residential usage is

\footnotetext{
* This chapter was overseen by Zhaoyuan Xu from the Development Research Center of the State Council and Martin Haigh from Shell International, with contributions from Baosheng Zhang and Shouhai Chen from the China University of Petroleum, Lianzeng Zhao from the China Petroleum Planning Research Institute, Linji Qiao from ENN and Juan Han from Shell China. Other members of the research group participated in discussions and revisions.
}

primarily with liquefied gas, artificial gas and electricity. In the heating and small-scale boiler sector, natural gas primarily competes with coal. In the industrial fuel sector, competition is primarily with fuel oil, artificial coal gas and coal. In the field of natural gas chemical engineering, competition is mainly with coal and naphtha. This section mostly consists of an analysis of price tolerance in these primary markets.

\subsection{Power Generation: Cost Comparison of Gas as a Substitute for Coal in Power Generation}

International experiences of development suggest that power generation is an important sector for natural gas. Natural gas power generation accounts for $39.4 \%$ of total installed capacity in the United States and 29\% in Japan, whereas this number is only about 3\% in China. China's natural gas power generation therefore has plenty of space to grow. In terms of its specific characteristics as a commodity, electricity is a classic homogenised product. Whether it is coal, hydroelectric, gas, wind or photovoltaic power, once it enters the grid, from the point of view of the end user it is essentially the same. It is primarily cost that affects the competitiveness of such commodities. 


\subsubsection{Direct Cost Comparison Between Gas Generation and Coal Generation}

In order to better compare and analyse gas power generation competitiveness and other factors affecting it, we adopted base-load coal power generation as the object of reference. Based on this, coal-fired units rely on the currently widely adopted ultra-super critical unit, with an installed scale of $600,000 / 1,000,000 \mathrm{~kW}$. For gas-fired units, the widely adopted 9F-grade CCGT unit was adopted, with an installed scale of 400,000 kW. Coal power generation baseline price was set at $550 \mathrm{CNY} /$ ton (price of 5500 kilocalorie power coal delivered to power station), which converts to a standard coal price of $700 \mathrm{CNY} /$ ton.

\section{Coal-fired power generation $\mathrm{kWh}$ total cost calculation}

The coal-fired power generation $1 \mathrm{kWh}$ cost primarily includes capital costs, non-fuel operational costs and fuel costs. Referring to national energy department reports and coal-fired power station feasibility reports, and supposing that a coal-fired power generating unit operating cycle is 20 years, the discount rate would be $9 \%$. Coal-fired generating units initially require a unit investment of $3900 \mathrm{CNY} / \mathrm{kW}$, with annual operating hours of 5000. Therefore, the capital cost of
$1 \mathrm{kWh}$ is $0.085 \mathrm{CNY} / \mathrm{kWh}$. Other costs of a $\mathrm{kWh}$ come to around $0.045 \mathrm{CNY} / \mathrm{kWh}$. When these are combined, the total is $0.13 \mathrm{CNY} / \mathrm{kWh}$, a figure close to the fixed cost of a $\mathrm{kWh}$. As far as fuel costs are concerned, $300 \mathrm{~g}$ of standard power coal is consumed on average, therefore the fuel cost of a $\mathrm{kWh}$ is around $0.21 \mathrm{CNY} / \mathrm{kWh}$. Combining these three together, the overall cost of a $\mathrm{kWh}$ is $0.34 \mathrm{CNY} / \mathrm{kWh}$ (see Fig. 3.1).

\section{Gas-fired power generation $\mathrm{kWh}$ total cost}

Combining research data and feasibility research report data, the initial unit investment for a gas-fired power unit was established to be $3000 \mathrm{CNY} / \mathrm{kW}$. Assuming that annual operating hours are $3500 \mathrm{~h}$ (at peak load and intermediate load), after conversion the capital cost of $1 \mathrm{kWh}$ is $0.094 \mathrm{CNY} / \mathrm{kWh}$. Based on research data, other operating costs for $1 \mathrm{kWh}$ are $0.065 \mathrm{CNY} / \mathrm{kWh}$. As regards fuel cost, depending on region and construction date, the price of gas supplied to power stations can differ significantly. This report uses south-eastern coastal areas as the main reference region, and adopts a price of $2.8 \mathrm{CNY} / \mathrm{m}^{3}$ as the basis for calculation. In terms of the gas required to generate $1 \mathrm{kWh}$, in actual gas-fired generation the differences in gas source result in fuels having different calorific values. There is quite a wide variation in the amount of gas consumed in power

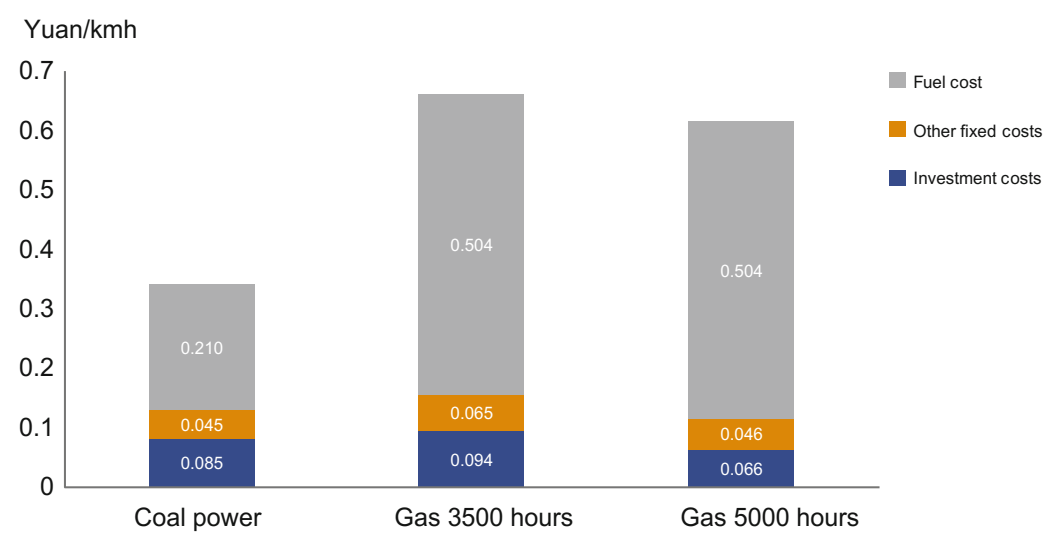

Fig. 3.1 Preliminary comparison of coal power generation and natural gas power generation costs 
generation. By combining research data, a figure for gas consumption related to power generation can be set at $0.18 \mathrm{~m}^{3} / \mathrm{kWh}$, which converts to a $\mathrm{kWh}$ fuel cost of $0.504 \mathrm{CNY} / \mathrm{kWh}$. Combining these three together, the overall cost of a $\mathrm{kWh}$ is $0.663 \mathrm{CNY} / \mathrm{kWh}$. If annual operating hours were raised to $5000 \mathrm{~h}$, the $1 \mathrm{kWh}$ fixed cost including capital costs and non-fuel related operating costs would drop, causing the cost of $1 \mathrm{kWh}$ to be reduced to $0.615 \mathrm{CNY} / \mathrm{kWh}$.

It is apparent from this comparison that, based on current energy source prices, the $1 \mathrm{kWh}$ cost for gas power generation is still far greater than coal, regardless of whether $3500-\mathrm{h}$ or 5000 -h operations are concerned. Looking at the direct costs, gas-fired generating units are not competitive. Even the fuel cost of gas-fired power generation alone (that is, the variable cost, or marginal cost) is much higher than total coal-fired power generation costs. This makes gas-fired generating units uncompetitive compared with coal-fired power generation, even if one ignores the fixed costs or where fixed costs have been covered by subsidies.

\section{Price tolerance calculations for gas-fired power generation}

Without considering changes to other factors, if gas-fired generating units were competitive with coal-fired power generation, then what level of gas price would we be talking about? Sensitivity analysis shows that when the gas $\mathrm{kWh}$ fuel cost is equivalent to the total cost of coal fuel, the natural gas price would drop to around 1.9 $\mathrm{CNY} / \mathrm{m}^{3}$, which is equivalent to European gas price levels. At this price level, due to the external benefits of gas-fired power generation, the fixed cost would attract a subsidy and gas would become competitive with coal. The sensitivity analysis shows that if the total fuel gas cost for $1 \mathrm{kWh}$ was required to be the same as the total cost of $1 \mathrm{kWh}$ generated with coal, then for an annual operation of $5000 \mathrm{~h}$, natural gas prices would need to drop to around $1.3 \mathrm{CNY} / \mathrm{m}^{3}$, while for $3500 \mathrm{~h}$ of operations it would need to drop to around $1.0 \mathrm{CNY} / \mathrm{m}^{3}$, which is trending closer to US gas prices.

\subsubsection{Other Factors Influencing the Competitiveness of Gas-Fired Power Generation}

Apart from the actual gas price, there are other factors that affect the competitiveness of gas-fired power generation, including those that have an effect on the internal costs of gas power generation and its associated external benefits.

\section{Localised production of core equipment for natural gas power generation}

In terms of core equipment, the overseas monopolies in turbine equipment and process control have led to long-term elevated equipment costs, while LTP, operating and maintenance fees are very high. An improvement in this situation would help to reduce the fixed $\mathrm{kWh}$ costs for gas power generation. If unit investment could be reduced by $15 \%$, it would also be possible to reduce the $\mathrm{kWh}$ cost by around $0.014 \mathrm{CNY} / \mathrm{kWh}$. At the same time, localisation of manufacture would reduce long-term maintenance and inspection costs. If overall maintenance fees could be reduced by $50 \%$, this would also bring about a reduction in the $\mathrm{kWh}$ cost of around $0.01 \mathrm{CNY} / \mathrm{kWh}$. By localising the manufacture of core equipment, the associated $\mathrm{kWh}$ cost could be reduced to a level around the $0.024 \mathrm{CNY} / \mathrm{kWh}$ mark.

\section{Operating hours}

By increasing the annual operating hours of generating units, it is possible to reduce the $\mathrm{kWh}$ fixed costs that need to be absorbed, thereby reducing gas power generation costs to a certain degree. However, the benefits of this decrease progressively. Based on the configuration data in this report, and by adopting sensitivity calculations, when generating unit operating times are respectively increased from $3500 \mathrm{~h}$ to 4000,4500 and $5000 \mathrm{~h}$, the respective cost reduction will be $0.02,0.035$ and $0.048 \mathrm{CNY} / \mathrm{kWh}$ (see Fig. 3.2).

There are many factors restricting natural gas installation operating hour increases. The first is a 


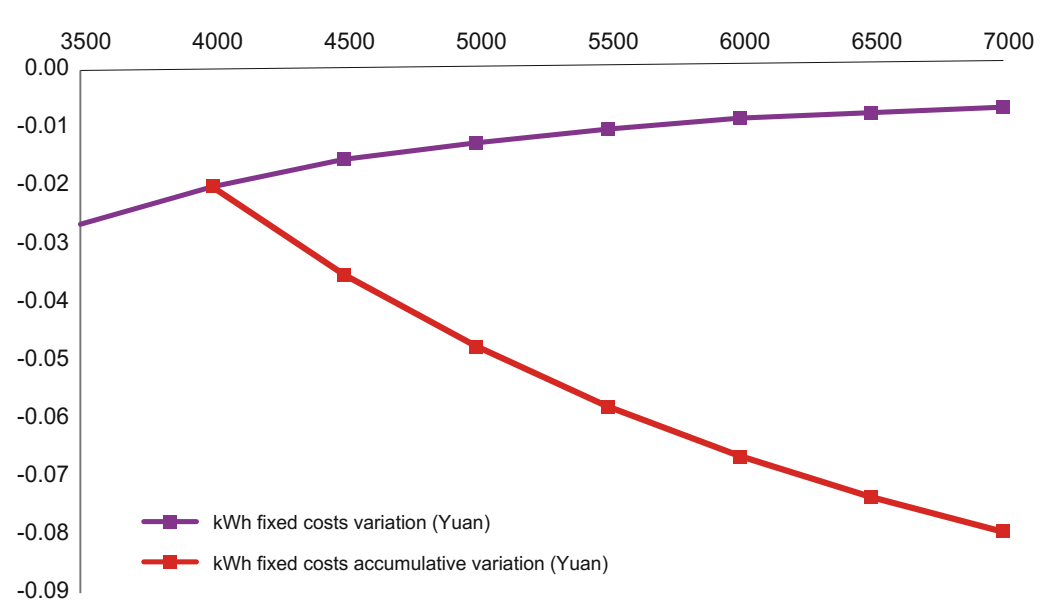

Fig. 3.2 Power generation cost analysis

high natural gas price and limited government subsidies, which greatly shorten the hours of power generation. Some new generating units that form part of this research were only capable of annual power generation of $1000 \mathrm{~h}$. In some locations, in order to cope with high gas prices, an approach had been adopted whereby coal-fired power stations were used as a proxy in power generation, but no solution was sought to resolve the fundamental issue of gas power generation facilities sitting idle. The second is that in south-eastern coastal areas, due to the lack of hydroelectric and other externally generated power for use in peak regulation, when major fluctuations in power demand occur, the effect of this is also felt on the operating hours of gas power generation. At the same time, frequent starting and stopping of operations also shortens the useful life of generating units and increases maintenance costs, none of which is beneficial to the long-term operation of gas power generating units.

\section{Emissions standards}

China has introduced relatively strict emissions standards with regard to coal-fired power generation. In September 2014, the three committees forming the National Development and Reform Commission issued the Coal Power Energy Savings and Emissions Reductions Upgrade and Reconditioning Action Plan (20142020), which makes clear pronouncements concerning strict control over emissions of atmospheric pollutants and which requires the atmospheric pollutant emissions concentrations ratings of newly built coal-fired generating units in eastern regions to conform to the restrictions applicable to gas turbine emissions (namely that with a baseline oxygen content of $6 \%$, smoke and dust, $\mathrm{SO}_{2}$ and nitrogen oxide concentration may not exceed 10, 35 and $50 \mathrm{mg} / \mathrm{m}^{3}$ ). Emissions ratings of newly built coal-fired generating units in central regions must approach or achieve the restrictions applied to gas turbine emissions, while emissions ratings of newly built coal-fired generating units in western regions are encouraged to approach or achieve the restrictions applied to gas turbine emissions. Apart from the addition of environmental installations, the plant operating modes were not changed. With regard to additional investment and the operational costs of such environmental installations, pricing conversions can be made with reference to the upgrades and modifications applied to the installations of certain current power stations and additional environmental investment encountered in new projects. After conversion, it was discovered that in order to comply with the strictest emissions standards, coal-fired power generation $\mathrm{kWh}$ costs rise by between around 0.01 and $0.02 \mathrm{CNY} / \mathrm{kWh}$. Large-scale generating unit costs increase slightly less, while cost increases are slightly higher for older and smaller units or where coal quality is poorer. 


\section{Carbon tax}

The high carbon emissions of coal power represent an important advantage for gas power. The price of carbon or the level of carbon tax is a critical factor influencing the competitiveness of gas power costs. Collection of carbon taxes will cause coal power and gas power $\mathrm{kWh}$ absolute costs to both rise. However, because coal power absolute cost increases will be greater, the difference in costs will result in the relative cost of carbon emissions associated with $1 \mathrm{kWh}$ for coal power being greater than for gas power. Based on various energy source emission product coefficients provided by the Shenzhen Carbon Exchange as well as IPCC report coefficients, it is possible to calculate the coal power carbon emissions as $0.8 \mathrm{~kg} / \mathrm{kWh}$ and gas power carbon emissions as $0.37 \mathrm{~kg} / \mathrm{kWh}$. As carbon prices rises, so does the carbon emission cost for coal power (Fig. 3.3). Taking as an example the Shenzhen Carbon Exchange June 18, 2013 online trading opening price of $30 \mathrm{CNY} /$ ton, the total increase in the relative cost of coal power was around $0.013 \mathrm{CNY} / \mathrm{kWh}$. Taking as an example the highest price listed on October 18, 2013 of $143.99 \mathrm{CNY} / \mathrm{ton}$, this affects the relative cost by around $0.06 \mathrm{CNY} / \mathrm{kWh}$.

\section{Auxiliary services}

Gas power auxiliary services refer to the system value of gas power in terms of adjustments during peak periods and as a back-up. The term also highlights the advantages of gas power over coal power as regards energy quality. Currently, with there being no auxiliary services market and no time-based power pricing mechanisms, capacity pricing based on a two-tier electricity price would take advantage of the benefits of auxiliary services. The determination of the capacity electricity price takes into consideration all aspects covered by gas power fixed costs, and can also be understood as including the additional investment in power capacity required to guarantee the reliability and stability of power supplies. Shanghai currently has power stations that implement a two-tier system for electricity pricing, with a gas power capacity price of $45.83 \mathrm{CNY} / \mathrm{kW} /$ month. In large cities such as Shanghai, Beijing and Shenzhen, where a two-tier system has been implemented, the industrial power price is between 40$44 \mathrm{CNY} / \mathrm{kW} / \mathrm{month}$. In overall terms, the influence of auxiliary services on competitiveness is fairly small.

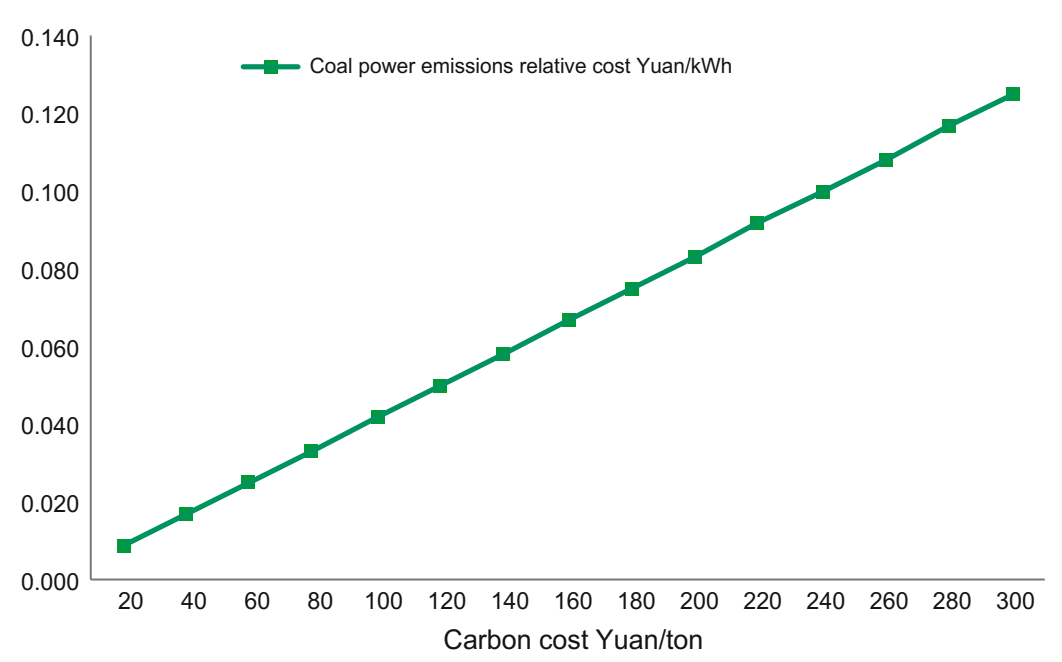

Fig. 3.3 Coal power emissions relative cost $(\mathrm{CNY} / \mathrm{kWh})$ 


\subsubsection{Conclusions Regarding the Prospects of Gas Replacing Coal in Power Generation}

Natural gas power generation competitiveness is determined by various relative costs. Here, the coal price adopted is $550 \mathrm{CNY} /$ ton. Based on the overall trends in coal prices since 2014, this is unlikely to increase in the short term. Regarding the natural gas price, considering that natural gas will gradually form a globalised market, with relatively large amounts of natural gas being imported by China, China's natural gas price will be inseparable from international gas prices. As things stand, increased marginal supply affecting the international natural gas market primarily comes from North American LNG, while East Asia is mainly responsible for marginal increases in consumption. Therefore, North American natural gas prices will have the greatest influence on LNG prices in East Asia. In fact, the biggest influence will be felt in China's south-eastern coastal regions, where there has been the greatest growth in natural gas power generation. Summarising forecast data from various research institutions, assuming a future US Henry Hub natural gas price of $5 \$ / M M B t u$, total $\mathrm{LNG}$ transportation fees of $5 \$ / M M B t u$ and a CIF price in China of $10 \$ / \mathrm{MMBtu}$, it would be necessary to reduce or exempt import duty on LNG. At the same time, for large power plant users near LNG receiving stations, the gas reception and piping costs can be estimated at $0.2 \mathrm{CNY} / \mathrm{m}^{3}$. This would result in the price of natural gas delivered to the power plant being 2.39 $\mathrm{CNY}$, which can be converted to a $\mathrm{kWh}$ cost of $0.43 \mathrm{CNY} / \mathrm{kWh}$.

\section{Comprehensive cost comparison for base loading power generation}

For a base loading generating unit $(5000 \mathrm{~h})$, the fuel cost based on an international gas price of $5 \$ / \mathrm{MMBtu}$ would be $0.43 \mathrm{CNY} / \mathrm{kWh}$, giving a $\mathrm{kWh}$ total cost of $0.541 \mathrm{CNY}$. By introducing localisation of equipment manufacturing, it would be possible to reduce $\mathrm{kWh}$ costs by $0.024 \mathrm{CNY}$. By increasing annual use to $6000 \mathrm{~h}$, costs could be reduced by $0.0185 \mathrm{CNY} / \mathrm{kWh}$, reducing the $\mathrm{kWh}$ cost of gas power to $0.499 \mathrm{CNY} / \mathrm{kWh}$. After the cost of emissions treatment has been applied to coal, the cost is still only $0.36 \mathrm{CNY} / \mathrm{kWh}$. If the carbon tax price is $120 \mathrm{CNY} / \mathrm{ton}$, then the cost of coal power would rise by $0.05 \mathrm{CNY} / \mathrm{kWh}$, reaching an overall cost of $0.41 \mathrm{CNY} / \mathrm{kWh}$. Therefore, gas power costs would still be higher than coal power by around $0.088 \mathrm{CNY} / \mathrm{kWh}$. As a result of this, gas power would not be competitive in China.

\section{General cost comparison of peak regulation}

When gas-fired peak regulation (annual operation of $3500 \mathrm{~h}$ ) is compared to base loading power generation, the greatest difference is that it allows the advantages of auxiliary generation services to be exploited. For example, by adopting capacity power pricing, once localised manufacturing has been taken into account, the compensatory level is around $39 \mathrm{CNY} / \mathrm{kW} /$ month, which converts to an electricity price of $0.134 \mathrm{CNY} / \mathrm{kWh}$. At the same time, if coal power emissions standards were very strict, the additional pollution processing costs would rise by $0.02 \mathrm{CNY} / \mathrm{kWh}$. Coal power $\mathrm{kWh}$ total costs would rise from $0.34 \mathrm{CNY} / \mathrm{kWh}$ to $0.36 \mathrm{CNY} / \mathrm{kWh}$. If the carbon tax rate was 120 $\mathrm{CNY} /$ ton, then coal power costs would rise by a further $0.05 \mathrm{CNY} / \mathrm{kWh}$. This would result in total coal power costs of $0.41 \mathrm{CNY} / \mathrm{kWh}$, while the gas power total cost would be $0.43 \mathrm{CNY} / \mathrm{kWh}$. Unless the carbon tax price is increased further, or government subsidies are increased, gas power will continue to lack a competitive advantage.

In overall terms, gas power lacks competitiveness with coal, not only at current gas price levels and in the current market environment, but even when the CIF price of international LNG is at the $\$ 10$ levels, under which circumstances gas power would still need a series of combined measures in order to achieve market competitiveness. Due to this, for a market to arise where gas power was able to develop would not only require changes in the global natural gas market, but also require the implementation of a series of wider-reaching policy measures. This would include providing encouragement for major 
scientific breakthroughs, gaining control over gas pricing mechanisms, streamlining the administration of the natural gas industry, the creation of liberalised gas and electricity pricing mechanisms and the internalisation of environmental costs and effects, particularly in terms of sensible carbon emissions pricing. Only then would growth in gas power generation become possible.

\subsection{Transport: Analysis of Natural Gas as a Substitute for Diesel}

Starting in the 1930s, when Italy promoted usage of natural gas in cars due to the petrol shortage at that time, there have been over 70 years of history of gas being used as vehicle fuel. However, transport is different from power generation in that its use in transport relies to some extent on user perception, energy source availability and transportation safety, while also being affected by external networks. The replacement of diesel by natural gas in the field of transportation would require system-wide adjustments and involve a relatively complex process.

\subsubsection{Primary Motivators for Natural Gas to Replace Diesel}

Looking at the development history of natural gas vehicles, safety, cleanliness and economy have all been primary motivators in promoting the development of natural gas cars. After the 1973 oil crisis, national worries about the safety of oil supplies resulted in greater attention being paid to the development of natural gas cars. In the 1980s, urban air quality problems resulting from vehicle exhaust pollution attracted increasing attention in Europe and North America, while the fact that levels of gas and emissions were much lower than petrol or diesel led to western countries, led by Italy, paying more attention to the promotion of natural gas cars. However, since the 1990s, as oil product quality and emissions control technology have improved, petrol and diesel vehicle pollution emissions have been greatly reduced and the advantages of natural gas in terms of cleanliness are no longer so pronounced. The pace of development of natural gas-powered vehicles in Europe and North America has now slowed. At the same time, up until around 2005, as international oil prices rose, the economic attraction of natural gas became more pronounced, and there was a rapid growth in the use of natural gas-powered cars in developing countries with relatively abundant gas resources.

Currently, in developed countries, oil supplies are relatively stable and there are fairly good oil reserves. Unless a major incident occurs, oil security has long since stopped being a driving factor for the development of natural gas vehicles. Moreover, with advances in engine technology, the advantages of natural gas cars as regards cleanliness have been reduced, reducing interest in the development of natural gas cars in developed countries. As regards economic factors, the energy consumption cost expenditure of European and North American users is relatively low, with more attention being paid to the driving experience, therefore without enhanced policies to drive forward the transition, the difference in price between diesel and gas would have no effect in terms of encouraging users to switch.

These factors exist to some extent in China as well, and in particular cleanliness and economy still play a major role in the rapid development and adoption of natural gas-powered vehicles. In terms of cleanliness, natural gas has the advantage of having a single component ingredient, allowing the easy removal of impurities, in addition to being of stable quality and having excellent physical characteristics, making it easier to improve cleanliness and meet emissions requirements. Of course, in developed countries, where oil quality is satisfactory and emissions control technologies are in place, petrol and diesel vehicles can meet the emissions levels of natural gas vehicles. Aside from this, vehicle emissions control requires the integration of fuel processing, engines controls, exhaust handling and other related technological systems and appropriately enhanced emissions standards. In China, due to the supply network and its locked-in nature, high 
levels of new investment in systems improvements and upgrades with a long-term strategy would be necessary to resolve problems relating to crude oil quality, refining processes, the vehicle industry and industrial standards that currently exist; natural gas, however, offers many advantages due to its cleanliness, as well as a good tolerance towards it in petrol engines, so its adoption would show quicker results in terms of environmental requirements.

The fact that China is a developing country means that economical fuel is still a major driver behind the development of natural gas as a transportation fuel. Fuel costs account for around $40 \%$ of operating costs, so reducing fuel costs is a major factor in making transport businesses more competitive. In the past few years, the significant difference in the price of diesel and gas and exemption from consumer taxes has resulted in the rapid development of natural gas vehicles in China. Taking CNG in taxis as an example, for a period of time the CNG price was just half that of petrol, meaning that the conversion cost could be recovered within a few months, resulting in rapid growth in the market for CNG in cars.

\subsubsection{Natural Gas Oil Replacement Price Tolerance in the Urban Transport Sector}

\section{Taxi natural gas petrol replacement price tolerance}

Urban CNG taxis and public transport are currently the largest markets for natural gas. CNG taxis are mainly being adopted in second- and third-tier cities, as well as in first-tier cities where natural gas was introduced relatively early, such as the cities in the Sichuan-Chongqing basin and in Chengdu. In some cities, adoption of natural gas fuel is almost universal. However, after rapid development in the past, this market has slowed in recent years. In first-tier cities where taxis did not invest in CNG early on, the high demand for land for urban development has made it difficult to site natural gas filling stations, which restricts the development of CNG taxis.

City taxis can use CNG to replace petrol, the cost of taxi conversion being around CNY 5000. Based on average distances travelled of $100,000 \mathrm{~km}$, and the cost of conversion being absorbed over a year, the conversion cost is $5 \mathrm{CNY} / 100 \mathrm{~km}$. The price tolerance of gas used as a replacement, based on the running costs for gas taxis being the same as for petrol taxis, is $5.58 \mathrm{CNY} / \mathrm{m}^{3}$ for an international crude oil price of $100 \$ / \mathrm{bbl}$, and $4.34 \mathrm{CNY} / \mathrm{m}^{3}$ when the international crude oil price is $60 \$ / \mathrm{bbl}$ (Table 3.1).

\section{Bus natural gas diesel replacement price tolerance}

Urban public transport is also an important submarket for CNG and LNG applications. Because public transport companies normally have their own bus stations, it is possible for them to construct $\mathrm{LNG/CNG}$ stations even in first-tier cities. As a result, there is greater potential for development.

Urban public transport vehicles can use CNG to replace diesel, and vehicle conversion costs around $\mathrm{CNY}$ 12,000. Basing calculations on

Table 3.1 Taxi price tolerance of natural gas as replacement for petrol

\begin{tabular}{|l|l|l|l|l|l|l|}
$\begin{array}{l}\text { International price } \\
\text { of crude oil }(\$ / \mathrm{bbl})\end{array}$ & $\begin{array}{l}\text { Petrol } \\
\text { Price } \\
(\mathrm{CNY} / \mathrm{L})\end{array}$ & $\begin{array}{l}\text { Oil } \\
\text { consumption } \\
(\mathrm{L} / 100 \mathrm{~km})\end{array}$ & $\begin{array}{l}\text { Fuel cost } \\
(\mathrm{CNY} / 100 \mathrm{~km})\end{array}$ & $\begin{array}{l}\text { Natural gas } \\
\text { Gas } \\
\text { consumption } \\
\left(\mathrm{m}^{3} / 100 \mathrm{~km}\right)\end{array}$ & $\begin{array}{l}\text { Conversion } \\
\text { cost } \\
(\mathrm{CNY} / 100 \mathrm{~km})\end{array}$ & $\begin{array}{l}\text { Price } \\
\text { tolerance } \\
\left(\mathrm{CNY} / \mathrm{m}^{3}\right)\end{array}$ \\
\hline 100 & 6.77 & 8 & 54 & 8.8 & 5 & 5.58 \\
80 & 6.08 & & 49 & & & 4.96 \\
60 & 5.39 & & 43 & & 4.34
\end{tabular}

Data source Results of calculation 
Table 3.2 Bus price tolerance of natural gas as replacement for diesel

\begin{tabular}{|l|l|l|l|l|l|l|}
\hline $\begin{array}{l}\text { International price of } \\
\text { crude oil }(\$ / \mathrm{bbl})\end{array}$ & $\begin{array}{l}\text { Diesel } \\
\text { Price } \\
(\mathrm{CNY} / \mathrm{L})\end{array}$ & $\begin{array}{l}\text { Oil } \\
\text { consumption } \\
(\mathrm{L} / 100 \mathrm{~km})\end{array}$ & $\begin{array}{l}\text { Fuel cost } \\
(\mathrm{CNY} / \mathrm{km})\end{array}$ & $\begin{array}{l}\text { Natural gas } \\
\text { Gas } \\
\text { consumption } \\
\left(\mathrm{m}^{3} / 100 \mathrm{~km}\right)\end{array}$ & $\begin{array}{l}\text { Conversion } \\
\text { cost }(\mathrm{CNY} / \mathrm{L})\end{array}$ & $\begin{array}{l}\text { Price } \\
\text { tolerance } \\
\left(\mathrm{CNY} / \mathrm{m}^{3}\right)\end{array}$ \\
\hline 100 & 6.72 & 35 & 235 & 38 & 15 & 5.80 \\
\hline 80 & 5.90 & & 206 & & & 5.04 \\
\hline 60 & 5.08 & & 178 & & 4.28 \\
\hline
\end{tabular}

Data source Results of calculation

recovering the cost of conversion over a year, with a distance travelled of $80,000 \mathrm{~km}$, the cost is the equivalent of an additional $15 \mathrm{CNY} / 100 \mathrm{~km}$. The price tolerance of gas used as a replacement, based on the running costs for gas buses being the same as for diesel buses, is $5.80 \mathrm{CNY} / \mathrm{m}^{3}$ when the international crude oil price is $100 \$ / \mathrm{bbl}$, and 4.28 $\mathrm{CNY} / \mathrm{m}^{3}$ when the international crude oil price is $60 \$ / \mathrm{bbl}$ (Table 3.2).

CNG private cars and light commercial vehicles also account for a share of the market, primarily concentrated in second- and third-tier cities where natural gas taxis are relatively well developed. Private cars are normally relatively economical low-end compact cars, such as those costing less than CNY 100,000. In the next 10 years, the market will remain relatively stable, and as income levels rise, new users will continue to enter the economy car market. However, at the same time, some of the original economy vehicle users will upgrade to mid-range and high-end vehicles. As for penetration of electric private vehicles, it is mainly in first-tier cities affected by vehicle policies, and especially in cities where license plate restrictions are in place, that there is a considerable variance in terms of market share when compared to $\mathrm{CNG}$ private vehicles, and as far as overall numbers go, this does not represent a major influence on the $\mathrm{CNG}$ private vehicle market at the present time. There has been relatively rapid growth in light commercial vehicles in the past two years, but numbers still remain low, as conversion of diesel engines presents problems, resulting in low levels of interest and indicating minimal market growth in the future.

\subsubsection{Commercial Vehicle Natural Gas Diesel Replacement Price Tolerance}

The commercial vehicle LNG market is the submarket with the greatest growth, and is primarily composed of heavy lorries, inter-city buses, medium-sized lorries, works vehicles and other vehicles. In terms of economic incentives or market scale, heavy lorries are the application market with the greatest growth potential. Moreover, long-distance inter-city buses, if travelling over $400 \mathrm{~km}$, also have a marked economic effect, but are affected in turn by the rapid development of high-speed rail and the quickness of air travel. It is expected that this market will tend to shrink. However, medium-sized lorries, works vehicles and other vehicles only make economic sense in regions where gas sources are relatively inexpensive, due to their relatively low fuel consumption. Since 2011, there has been a rapid increase in the construction of LNG filling stations, and the expectation is that by 2020 filling station coverage will include major ports, industrial parks and main logistics routes. Moreover, as networks are optimised, the growth in numbers of LNG vehicles will outrun the increase in LNG filling stations, resulting in increased operational efficiency and profitability of LNG filling stations, and the emergence of a self-sustaining cycle in this industry.

We calculated the commercial vehicle price tolerance taking inter-city long-distance heavy lorries as an example. Inter-city long-distance lorries can use liquefied natural gas (LNG) instead of diesel. The purchase price of LNG vehicles is 
Table 3.3 Transport lorry price tolerance of natural gas as replacement for diesel

\begin{tabular}{|l|l|l|l|l|l|l|}
\hline $\begin{array}{l}\text { International } \\
\text { price of crude oil } \\
(\$ / \mathrm{bbl})\end{array}$ & $\begin{array}{l}\text { Diesel } \\
\text { Price } \\
(\mathrm{CNY} / \mathrm{L})\end{array}$ & $\begin{array}{l}\text { Oil } \\
\text { consumption } \\
(\mathrm{L} / 100 \mathrm{~km})\end{array}$ & $\begin{array}{l}\text { Fuel cost } \\
(\mathrm{CNY} / 100 \mathrm{~km})\end{array}$ & $\begin{array}{l}\text { Natural gas } \\
\text { Gas } \\
\text { consumption } \\
\left(\mathrm{m}^{3} / 100 \mathrm{~km}\right)\end{array}$ & $\begin{array}{l}\text { Price } \\
(\mathrm{CNY} / \mathrm{L})\end{array}$ & $\begin{array}{l}\text { Price } \\
\text { tolerance } \\
\left(\mathrm{CNY} / \mathrm{m}^{3}\right)\end{array}$ \\
\hline 100 & 6.72 & 45 & 302 & 50 & 45 & 5.15 \\
\hline 80 & 5.90 & & 265 & & 4.41 \\
\hline 60 & 5.08 & & 229 & & 3.67 \\
\hline
\end{tabular}

Data source Results of calculation

higher by roughly CNY 90,000 than that of diesel vehicles. Basing calculations on annual travel of $100,000 \mathrm{~km}$, and recovering the cost of conversion over $50 \%$ of the vehicle scrapping distance, the calculated cost is the equivalent of an additional 45 (37.5) CNY/100 km. The price tolerance of gas used as a replacement for diesel, based on the running costs for gas commercial vehicles being the same as for diesel commercial vehicles, is $5.15 \mathrm{CNY} / \mathrm{m}^{3}$ when the international crude oil price is $100 \$ / \mathrm{bbl}$, and $3.67 \mathrm{CNY} / \mathrm{m}^{3}$ when the international crude oil price is $60 \$ / \mathrm{bbl}$ (Table 3.3).

\subsubsection{Ship Transport Natural Gas Diesel Replacement Price Tolerance}

Waterborne transport relying on LNG is a submarket that is just starting to develop. Ships consume considerable amounts of fuel, and shipping routes are relatively fixed and generally linear in their distribution. There are low external requirements for filling station networks, and with mature technology and commercial models, rapid development is likely. Currently, ship fuels are divided into light oil and heavy oil. Because heavy oil prices are low, LNG is not competitive. The main market for LNG is as a replacement for light oil. Light oil use is primarily concentrated in interior river systems and used in river transport, dredging and works vessels, as well as being used by some coastal fishing boats. Interior river goods vessels have stable annual oil consumption, have fixed routes and can normally fill up at service areas. There are not that many dredgers, but they have high fuel consumption, refill frequently, have stable fuel consumption and have relatively dense concentrations, making it possible to construct dedicated filling stations. These two types of user are submarkets that could be reasonably easily developed. Even though coastal fishing boats are numerous, they are affected by factors such as the fishing season and have some seasonal variances with non-fixed routes and irregular operation, accompanied by rapid deterioration, therefore short-term development will be slow. Currently, LNG shipping applications are being promoted heavily by central and local government. Because single unit fuel consumption is considerable, economy of scale is particularly pronounced. Compared to constructing an LNG filling station network, adding filling stations along shipping routes is much simpler and more convenient. Once conditions develop, this market will easily pick up, and it requires only a short development cycle.

Price tolerance for shipping to use LNG instead of oil is relatively high. Basing calculations on a 2000 ton grade dual-fuel $(30 \%$ diesel $+70 \%$ LNG) powered ship, the conversion cost is CNY 750,000. Based on 10 journeys per year, each voyage being $1250 \mathrm{~km}$, and offsetting the conversion costs over 5 years of voyages, the conversion cost works out at $1200 \mathrm{CNY} / 100 \mathrm{~km}$. The price tolerance of gas used as a replacement for diesel, based on the running costs for gas-powered vessels being the same as for diesel vessels, is $4.96 \mathrm{CNY} / \mathrm{m}^{3}$ when the international crude oil price is $100 \$ / \mathrm{bbl}$, and the price tolerance is $3.47 \mathrm{CNY} / \mathrm{m}^{3}$ when the international 
Table 3.4 Shipping price tolerance of natural gas as replacement for diesel

\begin{tabular}{|c|c|c|c|c|c|c|}
\hline \multirow{2}{*}{$\begin{array}{l}\text { International } \\
\text { price of crude oil } \\
(\$ / b b l)\end{array}$} & \multicolumn{2}{|l|}{ Diesel } & \multirow{2}{*}{$\begin{array}{l}\text { Fuel cost } \\
(\mathrm{CNY} / 100 \mathrm{~km})\end{array}$} & \multicolumn{3}{|l|}{ Natural gas } \\
\hline & $\begin{array}{l}\text { Price } \\
(\mathrm{CNY} / \mathrm{L})\end{array}$ & $\begin{array}{l}\text { Oil } \\
\text { consumption } \\
(\mathrm{L} / 100 \mathrm{~km})\end{array}$ & & $\begin{array}{l}\text { Gas } \\
\text { consumption } \\
\left(\mathrm{m}^{3} / 100 \mathrm{~km}\right)\end{array}$ & $\begin{array}{l}\text { Price } \\
(\mathrm{CNY} / \mathrm{L})\end{array}$ & $\begin{array}{l}\text { Price } \\
\text { tolerance } \\
\left(\mathrm{CNY} / \mathrm{m}^{3}\right)\end{array}$ \\
\hline 100 & 6.72 & \multirow[t]{3}{*}{950} & 6384 & \multirow[t]{3}{*}{1045} & \multirow[t]{3}{*}{1200} & 4.96 \\
\hline 80 & 5.90 & & 5605 & & & 4.21 \\
\hline 60 & 5.08 & & 4825 & & & 3.47 \\
\hline
\end{tabular}

Data source Results of calculation

crude oil price is $60 \$ / \mathrm{bbl}$. Pricing parity for natural gas versus diesel is around 0.70 (Table 3.4).

\subsubsection{General Factors in the Transportation Market Relating to Gas Replacement of Diesel}

Even though natural gas is currently the most realistic alternative transportation fuel, and its clean, low-carbon and economical qualities mean that it has great potential in China, the realisation of this presents many challenges. In addition to economy, factors affecting the switch from oil to natural gas include natural gas supply, development of natural gas transport modes, natural gas filling stations, consumer expectations and the development of electrically powered cars.

\section{Assurances related to natural gas and transportation usage}

In terms of natural gas fuel, users primarily focus on assurances concerning gas supplies, price and quality. Currently, as transitions take place in the layout of global natural gas supplies and demand, and China's natural gas supplies diversify, it can be expected that natural gas supplies will be fully guaranteed in the future. It is therefore to be expected that concerns about natural gas supply guarantees will no longer play a major role. Natural gas prices, pricing mechanisms and price development trends play a more significant role. In terms of quality, unlike in power generation, consumers focus more on the calorific value of natural gas.

\section{Extent of deployment of natural gas filling stations}

The extent of deployment of natural gas filling stations is an important factor affecting the convenience of vehicle operation. Transportation is affected by network externalities, and as more filling stations come on line, this will attract new users and create wider network benefits. This will, in turn, increase the value of new and existing filling stations, creating a virtuous circle that increases the use of gas in transport.

\section{Development of natural gas transportation}

Transportation using natural gas currently includes CNG vehicles, LNG vehicles and LNG shipping, and involves manufacturing or conversion, operation, maintenance and scrapping. CNG vehicles are primarily compact cars, light goods vehicles and buses. Because CNG and petrol both use a combustion engine, the manufacture, conversion and maintenance processes are simple. Currently the main problem encountered is that public transport departments are worried that converted vehicles present a safety hazard. LNG vehicles are primarily used as heavy lorries, light commercial vehicles, inter-city passenger vehicles and in other long-distance uses where vehicles consume large quantities of fuel. They can also be used in mining, engineering and other sectors. Vehicle conversion requires return to the factory, but the 
technology is mature. The cost of switching from diesel to LNG is relatively high due to the small scale on which it occurs. In addition, LNG vehicle repair shops are few and far between. If a malfunction occurs, it is often necessary to return the vehicle to the factory for repair, resulting in inconvenience and financial losses being incurred by the user. LNG ships are currently in the trial adoption stage. Depending on the type of combustion engine that vessels rely on, conversion to LNG may require a return to the factory in order to convert the engine to the spark ignition type. Alternatively, conversion may be to a mixed diesel/LNG type engine, and appropriate conversion schemes still require improvement through further trials.

\section{User perception also influences replace- ment of oil-based fuels with natural gas}

User perception is the subjective experience of the user relating to the use of natural gas in transportation, and this has an important influence on the development of natural gas transportation and in the analysis of submarkets. User perception includes three aspects: performance, user sensitivity and usage environment.

In terms of performance, natural gas vehicles vary somewhat from petrol vehicles. Compared to petrol, the burn rate of natural gas is slower, the theoretical highest burn temperature is lower, and the amount of air required during the burn process is greater. At the same time, to accommodate burning of both fuels, the engine is often not configured to the optimal state to use natural gas. These factors each influence the drive output of natural gas engines, fuel efficiency and other aspects. In terms of user sensitivity, this involves fuel economy, power output, usage space, convenience and many other factors. For example, commercial vehicles focus more on economy and factors related to economy, whereas private vehicles focus more on output, usage space, cleanliness etc. In terms of usage environment, electric cars have also been labelled as innovative, technologically advanced, fashionable and environmentally friendly alternatives to both gas and petrol vehicles, whereas gas-fuelled private vehicles tend to have an image of being more affordable.

\section{Other threats posed by replacement with electric cars}

Compared to natural gas vehicles, electric cars offer some competitive advantages, and therefore could present fierce competition to natural gas vehicles. First, electric motor efficiency is inherently higher than that of the internal combustion engine, there being less mechanical wear in the electric car drive mechanism; as a result of this, less energy is consumed than with internal combustion engine cars. Moreover, electric motors emit essentially zero emissions. Second, in terms of output and performance, output in electric cars can be increased through simple changes to voltage, current and frequency. Their structure is more compact, while they have a flexible driving dynamic. Finally, in terms of economy, even though current purchase costs are high, they become more economical as driving distance increases.

Currently, the greatest obstacle to the development of electric vehicles comes from insufficient battery recharging facilities, in addition to which battery costs are high and there are challenges when it comes to extending voyage distances. The potential threat that electric cars pose to natural gas-powered cars and the space their development occupies depends on the technological development of electric vehicles, and the speed at which battery exchange and charging facilities can be extended.

\subsubsection{Potential Prospects for Transportation Market Natural Gas Demand}

In 2013, natural gas vehicles used around 12 billion $\mathrm{m}^{3}$ nationally. Of this, CNG vehicles used around 10 billion $\mathrm{m}^{3}$, and LNG vehicles used 2 billion $\mathrm{m}^{3}$. Because natural gas is still the most practical alternative fuel for transportation compared to other alternative fuels, it has a relatively large potential for development. 
Looking at the larger picture, markets for vehicles using CNG will gradually enter a period of slower development, with expectations that this growth will be slightly higher or equivalent to natural gas consumption market growth rates. By 2020, consumption will reach 20 billion $\mathrm{m}^{3}$, and by 2025 it will reach 25 billion $\mathrm{m}^{3}$, after which growth will stagnate.

LNG vehicle markets in the next 10 years will maintain high rates of growth, with expectations that in 2020 vehicular use of LNG will exceed 20 billion $\mathrm{m}^{3}$. By 2030, that number is expected to reach 40 billion $\mathrm{m}^{3}$.

Shipping LNG is also an important potential market, but conversion schemes and commercial models have yet to be further optimised. Moreover, interior river system markets using light oil only have small capacity, whereas coastal shipping still depends on the degree of implementation of environmental policy. Early development is therefore expected to be slow, with later development depending on changes in environmental protection policies. Optimistic projections for ship usage of LNG envisage usage exceeding 2 billion $\mathrm{m}^{3}$ by 2020 , and over 10 billion $\mathrm{m}^{3}$ by 2030 .

\subsection{Urban Use: Assessment of Price Tolerance for Natural Gas to Replace Other Fuels}

\subsubsection{Price Tolerance is Relatively High for Residential Usage of Natural Gas}

Urban residential usage of natural gas is primarily for cooking, hot water and heating systems. Gas use indices are affected largely by lifestyle, infrastructure and price. Based on calculations in the Urban and Rural Construction Statistical Yearbook 2012, per capita natural gas usage across China in 2012 was $73 \mathrm{~m}^{3}$. However, in regions such as Sichuan and Chongqing, where there are more abundant resources, the price is lower, and where urban introduction occurred early on, this figure reaches $120 \mathrm{~m}^{3}$. In major cities there is a high quality of life required and they exhibit a higher range of $70-80 \mathrm{~m}^{3}$. Other cities generally have a range of $50-60 \mathrm{~m}^{3}$.

Residential options for energy sources include electricity, bottled liquefied gas and natural gas. Therefore, natural gas, liquefied gas and electricity compete to replace each other in urban residential usage. Since electricity replaced coal, urban residential usage of natural gas has an indirect relationship of acting as a substitute for coal.

\section{Price tolerance for natural gas to replace liquefied gas}

Liquefied gas is a by-product of the oil refining process, and its price is very much related to the price of crude oil. When the international price of crude oil is $100 \$ / \mathrm{bbl}$, household bottled liquefied gas costs $8.23 \mathrm{CNY} / \mathrm{kg}$, and when the international price of crude oil is $60 \$ / \mathrm{bbl}$, household bottled liquefied gas costs $6.64 \mathrm{CNY} / \mathrm{kg}$.

The heat efficiency of urban residential piped natural gas and bottled liquefied gas is around $60 \%$. Basing calculations on the principle of equivalent effective calorific value costs, the price tolerance for natural gas as a replacement for liquefied gas can be calculated as $5.62 \mathrm{CNY} / \mathrm{m}^{3}$ when the international price of crude oil is $100 \$ / \mathrm{bbl}$ and $4.54 \mathrm{CNY} / \mathrm{m}^{3}$ when the international price of crude oil is $60 \$ / \mathrm{bbl}$ (Table 3.5).

\section{Price tolerance for natural gas to replace electricity}

Electricity is a clean and efficient household energy source. When natural gas prices are not competitive with those of electricity, residents will switch to using electrical appliances, for example switching from a natural gas hot water heater to an electrical hot water heater. Based on the available information, residential natural gas heat efficiency is around $75 \%$, whereas electric hot water heat efficiency is around $98 \%$. Calculating the price tolerance of natural gas to replace electricity based on the principle of equivalent effective calorific value cost, with current residential electricity 
Table 3.5 Price tolerance for residential usage natural gas replacement of liquefied gas

\begin{tabular}{|l|l|l|l|l|l|l|l|}
\hline $\begin{array}{l}\text { International } \\
\text { crude oil } \\
\text { price }(\$ / \mathrm{bbl})\end{array}$ & $\begin{array}{l}\text { Small bottle liquefied gas } \\
\text { Price }\end{array}$ & $\begin{array}{l}\text { Calorific } \\
\text { (CNY/kg) }\end{array}$ & $\begin{array}{l}\text { Calorific } \\
\text { value } \\
\text { efficiency }\end{array}$ & $\begin{array}{l}\text { Effective } \\
\text { calorific } \\
\text { value cost } \\
(\mathrm{CNY} / \mathrm{kJ})\end{array}$ & $\begin{array}{l}\text { Natural gas } \\
\text { Calorific } \\
\text { efficiency }\end{array}$ & $\begin{array}{l}\text { Calorific } \\
\text { value } \\
\left(\mathrm{MJ} / \mathrm{m}^{3}\right)\end{array}$ & $\begin{array}{l}\text { Price } \\
\text { tolerance } \\
\left(\mathrm{CNY} / \mathrm{m}^{3}\right)\end{array}$ \\
\hline 100 & 8.23 & 50.25 & $60 \%$ & 273 & $60 \%$ & 34.34 & 5.62 \\
80 & 7.43 & & & 246 & & & 5.08 \\
60 & 6.64 & & & 220 & & 4.54
\end{tabular}

Data source Results of calculation

Table 3.6 Price tolerance for residential usage natural gas replacement of electricity

\begin{tabular}{|l|l|l|l|l|l|l|}
\hline $\begin{array}{l}\text { Residential electricity } \\
\begin{array}{l}\text { Price } \\
(\mathrm{CNY} / \mathrm{kWh})\end{array}\end{array}$ & $\begin{array}{l}\text { Calorific } \\
\text { value } \\
(\mathrm{MJ} / \mathrm{kWh})\end{array}$ & $\begin{array}{l}\text { Calorific } \\
\text { efficiency }\end{array}$ & $\begin{array}{l}\text { Effective calorific } \\
\text { value cost } \\
(\mathrm{CNY} / \mathrm{GJ})\end{array}$ & $\begin{array}{l}\text { Natural gas } \\
\text { Calorific } \\
\text { efficiency }\end{array}$ & $\begin{array}{l}\text { Calorific } \\
\text { value } \\
\left(\mathrm{MJ} / \mathrm{m}^{3}\right)\end{array}$ & $\begin{array}{l}\text { Price } \\
\text { tolerance } \\
\left(\mathrm{CNY} / \mathrm{m}^{3}\right)\end{array}$ \\
\hline 0.6 & 3.60 & $98 \%$ & 170 & $75 \%$ & 34.34 & 4.38 \\
0.5 & & & 142 & & 3.65 \\
0.4 & & 113 & & 2.92 \\
\hline
\end{tabular}

Data source Results of calculation

Table 3.7 Residential disposable income price tolerance for natural gas

\begin{tabular}{|c|c|c|c|c|}
\hline Income group & $\begin{array}{l}\text { Per-capita disposable } \\
\text { income (CNY/year) }\end{array}$ & $\begin{array}{l}\text { Upper limit of residential } \\
\text { fuel expenditure (CNY/year) }\end{array}$ & $\begin{array}{l}\text { Resident average } \\
\text { gas usage }\left(\mathrm{m}^{3} / \text { year }\right)\end{array}$ & $\begin{array}{l}\text { Acceptable natural } \\
\text { gas price }\left(\mathrm{CNY} / \mathrm{m}^{3}\right)\end{array}$ \\
\hline High income & 56,389 & 1692 & \multirow[t]{5}{*}{60} & 28.2 \\
\hline $\begin{array}{l}\text { Mid- to high } \\
\text { income }\end{array}$ & 32,415 & 972 & & 16.2 \\
\hline Middle income & 24,518 & 736 & & 12.3 \\
\hline $\begin{array}{l}\text { Mid- to low } \\
\text { income }\end{array}$ & 18,483 & 554 & & 9.2 \\
\hline Low income & 11,434 & 343 & & 5.7 \\
\hline
\end{tabular}

Data source Results of calculation

prices being $0.40-0.60 \mathrm{CNY} / \mathrm{kWh}$, natural gas price tolerance as a replacement for electricity is 2.92-4.38 CNY $/ \mathrm{m}^{3}$ (Table 3.6).

\section{Natural gas price tolerance in terms of disposable income of urban residents}

Compared to liquefied gas, natural gas is convenient, does not require bottling or transport and avoids the inconvenience of frequent replacement. It is symbolic of quality of life, and thus even if natural gas use has a higher cost than liquefied gas, residents will still opt to use natural gas, so long as the cost is within the range tolerable to their income level.

According to Price Law, residential use natural gas is a public commodity and is included in the scope of government price setting. Government procedures must be followed, and the most important factor from the point of view of government price setting is the disposable income level of urban residents. A level of average residential usage of $3 \%$ of the disposable income of low-income residents is used as a reference, resulting in an acceptable residential natural gas price of $5.7 \mathrm{CNY} / \mathrm{m}^{3}$ (Table 3.7). 


\subsubsection{Price Tolerance is also Quite Resilient in Commercial Service Natural Gas Use}

Commercial service natural gas users primarily include airports, government institutions, employee canteens, kindergartens, schools, hotels, restaurants, the catering industry, shopping centres and office buildings. Individual unit usage is far higher than that of residential users, with usage primarily for cooking and for cooling and heating systems. Alternatives include liquefied gas and electricity.

\section{Price tolerance of natural gas replacing liquefied gas}

Unlike residential users of liquefied gas, commercial service users generally use large tanks of liquefied gas, the price of which is lower than that of the smaller bottles of liquefied gas used residentially. Basing calculations on the principle of equivalent effective calorific value costs, the price tolerance for natural gas replacing liquefied gas can be calculated as $5.34 \mathrm{CNY} / \mathrm{m}^{3}$ when the international price of crude oil is
$100 \$ / \mathrm{bbl}$ and $4.31 \mathrm{CNY} / \mathrm{m}^{3}$ when the international price of crude oil is $60 \$ / \mathrm{bbl}$ (Table 3.8).

\section{Price tolerance of natural gas replacing electricity}

Among commercial service and institutional users, there is a competitive alternative relationship between natural gas and electricity in the promotion of natural gas direct combustion air conditioning units (Table 3.9). Basing calculations on the principle of equivalent effective calorific value costs, the price tolerance for natural gas replacing electricity can be calculated as $4.52 \mathrm{CNY} / \mathrm{m}^{3}$ when the international price of crude oil is $100 \$ / \mathrm{bbl}$ and $3.01 \mathrm{CNY} / \mathrm{m}^{3}$ when the international price of crude oil is $60 \$ / b b l$.

\subsubsection{Price Tolerance is Weak for Centralised Urban Heating Using Natural Gas}

China's centralised heating is primarily focused in the northern regions. The traditional areas relying on winter season heating are the three north-eastern

Table 3.8 Price tolerance for commercial service usage of natural gas as replacement for liquefied gas

\begin{tabular}{|l|l|l|l|l|l|l|l|}
\hline $\begin{array}{l}\text { International } \\
\text { crude oil } \\
\text { price }(\$ / \mathrm{bbl})\end{array}$ & $\begin{array}{l}\text { Large tank liquefied gas } \\
\text { Price } \\
(\mathrm{CNY} / \mathrm{kg})\end{array}$ & $\begin{array}{l}\text { Calorific } \\
\text { value } \\
(\mathrm{MJ} / \mathrm{kg})\end{array}$ & $\begin{array}{l}\text { Calorific } \\
\text { efficiency }\end{array}$ & $\begin{array}{l}\text { Effective } \\
\text { calorific } \\
\text { value cost } \\
(\mathrm{CNY} / \mathrm{GJ})\end{array}$ & $\begin{array}{l}\text { Natural gas } \\
\text { Calorific } \\
\text { efficiency }\end{array}$ & $\begin{array}{l}\text { Calorific } \\
\text { value } \\
\left(\mathrm{MJ} / \mathrm{m}^{3}\right)\end{array}$ & $\begin{array}{l}\text { Price } \\
\text { tolerance } \\
\left(\mathrm{CNY} / \mathrm{m}^{3}\right)\end{array}$ \\
\hline 100 & 7.82 & 50.25 & $50 \%$ & 311 & $50 \%$ & 34.34 & 5.34 \\
\hline 80 & 7.06 & & 281 & & & 4.82 \\
\hline 60 & 6.31 & & 251 & & 4.31
\end{tabular}

Data source Results of calculation

Table 3.9 Price tolerance for commercial service usage of natural gas as a replacement for electricity

\begin{tabular}{|c|c|c|c|c|c|c|c|c|}
\hline \multicolumn{4}{|c|}{ Commercial usage of electricity } & \multirow{2}{*}{$\begin{array}{l}\text { Effective } \\
\text { calorific value } \\
\text { cost }(\mathrm{CNY} / \mathrm{GJ})\end{array}$} & \multicolumn{4}{|l|}{ Natural gas } \\
\hline $\begin{array}{l}\text { Price } \\
(\mathrm{CNY} / \mathrm{kWh})\end{array}$ & $\begin{array}{l}\text { Calorific } \\
\text { value } \\
(\mathrm{MJ} / \mathrm{kWh})\end{array}$ & $\begin{array}{l}\text { Conversion } \\
\text { efficiency }\end{array}$ & $\begin{array}{l}\text { Conversion } \\
\text { cost } \\
(\mathrm{CNY} / \mathrm{GJ})\end{array}$ & & $\begin{array}{l}\text { Conversion } \\
\text { cost } \\
(\mathrm{CNY} / \mathrm{GJ})\end{array}$ & $\begin{array}{l}\text { Conversion } \\
\text { efficiency }\end{array}$ & $\begin{array}{l}\text { Calorific } \\
\text { value } \\
\left(\mathrm{MJ} / \mathrm{m}^{3}\right)\end{array}$ & $\begin{array}{l}\text { Price } \\
\text { tolerance } \\
\left(\mathrm{CNY} / \mathrm{m}^{3}\right)\end{array}$ \\
\hline 0.6 & \multirow[t]{3}{*}{3.60} & \multirow[t]{3}{*}{$95 \%$} & \multirow[t]{3}{*}{300} & 475 & \multirow[t]{3}{*}{320} & \multirow[t]{3}{*}{$75 \%$} & \multirow[t]{3}{*}{34.34} & 4.00 \\
\hline 0.5 & & & & 446 & & & & 3.25 \\
\hline 0.4 & & & & 417 & & & & 2.50 \\
\hline
\end{tabular}

Data source Results of calculation 
Table 3.10 Urban centralised heating price tolerance of natural gas as a replacement for coal

\begin{tabular}{|l|l|l|l|l|l|l|l|l|}
\hline $\begin{array}{l}\text { Coal } \\
\text { Price } \\
(\mathrm{CNY} / \mathrm{ton})\end{array}$ & $\begin{array}{l}\text { Calorific } \\
\text { value } \\
(\mathrm{MJ} / \mathrm{kg})\end{array}$ & $\begin{array}{l}\text { Consumed } \\
\text { amount } \\
\left(\mathrm{kg} / \mathrm{m}^{2}\right)\end{array}$ & $\begin{array}{l}\text { Conversion } \\
\text { cost } \\
\left(\mathrm{CNY} / \mathrm{m}^{2}\right)\end{array}$ & $\begin{array}{l}\text { Heating } \\
\text { cost } \\
\left(\mathrm{CNY} / \mathrm{m}^{2}\right)\end{array}$ & $\begin{array}{l}\text { Natural gas } \\
\text { Conversion } \\
\text { cost } \\
\left(\mathrm{CNY} / \mathrm{m}^{2}\right)\end{array}$ & $\begin{array}{l}\text { Consumed } \\
\text { amount } \\
\left(\mathrm{m}^{3} / \mathrm{m}^{2}\right)\end{array}$ & $\begin{array}{l}\text { Calorific } \\
\text { value } \\
\left(\mathrm{MJ} / \mathrm{m}^{3}\right)\end{array}$ & $\begin{array}{l}\text { Price } \\
\text { tolerance } \\
\left(\mathrm{CNY} / \mathrm{m}^{3}\right)\end{array}$ \\
\hline 800 & 20.94 & 30 & 12 & 36 & 9 & 12 & 34.34 & 2.25 \\
\hline 600 & & & & 30 & & & & 1.75 \\
\hline 400 & & & & 24 & & & 35 & \\
\hline
\end{tabular}

Data source Results of calculation

provinces, five north-western provinces, five north China provinces and Shandong and Henan, giving a total of 15 provinces (regions, cities), most of which rely on coal-fired boilers. Conversion from coal to natural gas has been carried out based on local environmental policy requirements. Basing calculations on the equivalent unit cost per heated area, when the coal price is $600 \mathrm{CNY} / \mathrm{ton}$, natural gas price tolerance as a replacement for coal is $1.75 \mathrm{CNY} / \mathrm{m}^{3}$ (Table 3.10).

\subsection{Industrial Use: Cost Comparison of Natural Gas Replacing Other Energy Sources}

Natural gas as an industrial fuel is primarily used in smelting furnaces, heating furnaces, hot treatment furnaces, roasting furnaces, drying furnaces and other industrial furnaces (construction materials, electromechanical, metals and other industries) and industrial furnaces used to generate steam for process requirements, and is used to replace fuel oil, coal gas and coal.

\subsubsection{Price Tolerance is Very Low for Replacement of Fuel Oil by Natural Gas in the Glass Industry}

Glass is primarily divided into flat panel glass and special type glass. Flat panel glass is divided into general flat panel glass and floating glass. The general process for the production of glass is: raw material-melting-forming-cooling-cutting-packing-placement into inventory-sale. Natural gas is primarily used at the melting stage, the main natural gas-consuming equipment being a glass furnace. Based on glass raw material melting principles, glass enterprises generally use high calorific value fuels such as fuel oil. Natural gas may therefore act as a substitute for fuel oil in the glass industry.

Basing calculations on the principle of equivalent effective calorific value costs, the price tolerance for natural gas replacing fuel oil can be calculated as $3.25 \mathrm{CNY} / \mathrm{m}^{3}$ when the international price of crude oil is $100 \$ / \mathrm{bbl}$ and $1.94 \mathrm{CNY} / \mathrm{m}^{3}$ when the international price of crude oil is $60 \$ / \mathrm{bbl}$ (Table 3.11).

Table 3.11 Glass industry price tolerance of natural gas as replacement for fuel oil

\begin{tabular}{|l|l|l|l|l|l|l|l|}
\hline $\begin{array}{l}\text { International } \\
\text { crude oil } \\
\text { price }(\$ / \mathrm{bbl})\end{array}$ & $\begin{array}{l}\text { Fuel oil } \\
\text { Price } \\
(\mathrm{CNY} / \mathrm{kg})\end{array}$ & $\begin{array}{l}\text { Calorific } \\
\text { value } \\
(\mathrm{MJ} / \mathrm{kg})\end{array}$ & $\begin{array}{l}\text { Heating } \\
\text { efficiency }\end{array}$ & $\begin{array}{l}\text { Effective } \\
\text { calorific } \\
\text { value cost } \\
(\mathrm{CNY} / \mathrm{GJ})\end{array}$ & $\begin{array}{l}\text { Natural gas } \\
\text { efficiency }\end{array}$ & $\begin{array}{l}\text { Calorific } \\
\text { value } \\
\left(\mathrm{MJ} / \mathrm{m}^{3}\right)\end{array}$ & $\begin{array}{l}\text { Price } \\
\text { tolerance } \\
\left(\mathrm{CNY} / \mathrm{m}^{3}\right)\end{array}$ \\
\hline 100 & 3.74 & 41.88 & $85 \%$ & 105 & $90 \%$ & 34.34 & 3.25 \\
\hline 80 & 2.98 & & & 84 & & & 2.59 \\
60 & 2.24 & & & 63 & & 1.94
\end{tabular}

Data source Results of calculation 


\subsubsection{Price Tolerance is Relatively Weak for the Ceramics Industry for Replacement of Coal Gas by Natural Gas}

The ceramics industry can be broken down into four sub-industries: hygiene ceramics, articles for everyday use, art and other ceramics. According to the production processes for ceramic products, the overall process is: raw material moulding and forming-firing - cooling and application of enamel-re-firing and other steps, with natural gas primarily used in kiln heating.

In order to guarantee the quality of the ceramic products, the fuel needs to be pure and without contaminating matter and the supply must be stable. Normally coal gas is used, but natural gas has the potential to be a substitute. Basing calculations on the principle of equivalent effective calorific value costs, the price tolerance for natural gas replacing coal gas can be calculated as $2.46 \mathrm{CNY} / \mathrm{m}^{3}$ when the price of coal is $600 \mathrm{CNY} /$ ton (Table 3.12).

\subsubsection{Natural Gas Price Tolerance is Relatively Poor for Steam Production as a Replace ment for Coal}

Steam is broadly used in industrial manufacturing processes, with steam generated by industrial boilers. Industrial boiler steam production does require much fuel, and normally low-priced coal is used. Therefore, in the industrial production of steam, natural gas has the potential to compete as a substitute for coal. Basing calculations on the principle of equivalent effective calorific value costs, the price tolerance for natural gas replacing coal can be calculated as $1.92 \mathrm{CNY} / \mathrm{m}^{3}$ when the price of coal is $600 \mathrm{CNY} /$ ton (Table 3.13).

Table 3.12 Ceramics industry natural gas price tolerance as a replacement for coal gas

\begin{tabular}{|c|c|c|c|c|c|c|c|}
\hline \multicolumn{4}{|l|}{ Coal } & \multirow{2}{*}{$\begin{array}{l}\text { Coal gas } \\
\text { calorific } \\
\text { value } \\
\left(\mathrm{MJ} / \mathrm{m}^{3}\right)\end{array}$} & \multirow{2}{*}{$\begin{array}{l}\text { Effective } \\
\text { calorific } \\
\text { value cost } \\
(\mathrm{CNY} / \mathrm{GJ})\end{array}$} & \multicolumn{2}{|c|}{ Natural gas } \\
\hline $\begin{array}{l}\text { Price } \\
\text { (CNY/ton) }\end{array}$ & $\begin{array}{l}\text { Calorific } \\
\text { value } \\
(\mathrm{MJ} / \mathrm{kg})\end{array}$ & $\begin{array}{l}\text { Conversion } \\
\text { efficiency } \\
\left(\mathrm{m}^{3} / \mathrm{kg}\right)\end{array}$ & $\begin{array}{l}\text { Conversion } \\
\text { cost } \\
\left(\mathrm{CNY} / \mathrm{m}^{3}\right)\end{array}$ & & & $\begin{array}{l}\text { Calorific } \\
\text { value } \\
\left(\mathrm{MJ} / \mathrm{m}^{3}\right)\end{array}$ & $\begin{array}{l}\text { Price } \\
\text { tolerance } \\
\left(\mathrm{CNY} / \mathrm{m}^{3}\right)\end{array}$ \\
\hline 800 & \multirow[t]{3}{*}{20.94} & \multirow[t]{3}{*}{3} & \multirow[t]{3}{*}{0.7} & \multirow[t]{3}{*}{16.75} & 82 & \multirow[t]{3}{*}{34.34} & 2.80 \\
\hline 600 & & & & & 72 & & 2.46 \\
\hline 400 & & & & & 62 & & 2.12 \\
\hline
\end{tabular}

Data source Results of calculation

Table 3.13 Industrial boiler steam production price tolerance of natural gas as a replacement for coal

\begin{tabular}{|c|c|c|c|c|c|c|c|c|}
\hline \multicolumn{4}{|l|}{ Coal } & \multirow{2}{*}{$\begin{array}{l}\text { Steam } \\
\text { cost } \\
\text { (CNY/ton) }\end{array}$} & \multicolumn{4}{|l|}{ Natural gas } \\
\hline $\begin{array}{l}\text { Price } \\
\text { (CNY/ton) }\end{array}$ & $\begin{array}{l}\text { Calorific } \\
\text { value } \\
(\mathrm{MJ} / \mathrm{kg})\end{array}$ & $\begin{array}{l}\text { Consumed } \\
\text { amount } \\
\text { (kg/ton) }\end{array}$ & $\begin{array}{l}\text { Conversion } \\
\text { cost (CNY/ton) }\end{array}$ & & $\begin{array}{l}\text { Conversion } \\
\text { cost } \\
\text { (CNY/ton) }\end{array}$ & $\begin{array}{l}\text { Consumed } \\
\text { amount } \\
\left(\mathrm{m}^{3} / \text { ton }\right)\end{array}$ & $\begin{array}{l}\text { Calorific } \\
\text { value } \\
\left(\mathrm{MJ} / \mathrm{m}^{3}\right)\end{array}$ & $\begin{array}{l}\text { Price } \\
\text { tolerance } \\
\left(\mathrm{CNY} / \mathrm{m}^{3}\right)\end{array}$ \\
\hline 800 & \multirow[t]{3}{*}{20.94} & \multirow[t]{3}{*}{200} & \multirow[t]{3}{*}{80} & 240 & \multirow[t]{3}{*}{50} & \multirow[t]{3}{*}{78} & \multirow[t]{3}{*}{34.34} & 2.44 \\
\hline 600 & & & & 200 & & & & 1.92 \\
\hline 400 & & & & 160 & & & & 1.41 \\
\hline
\end{tabular}

Data source Results of calculation 


\subsection{Chemicals: Potential for Increased Natural Gas Use in the Production Process}

Natural gas chemical engineering refers to the use of methane, the primary component of natural gas, in manufacturing processes, the products of which are primarily synthetic ammonia, methanol and hydrogen.

\subsubsection{Price Tolerance of Natural Gas is Extremely Low for the Manufacture of Synthetic Ammonia}

Production capacity and production volume in China's synthetic ammonia industry are the highest in the world, and coal and natural gas are the main raw materials, accounting for 76 and $22 \%$ respectively. The price of the final urea product is essentially guided by the production cost of the coal raw material. Thus, from the perspective of industry development, natural gas competes as an alternative to coal in the manufacture of synthetic ammonia.
Basing calculations on the principle of equivalent finished product costs, the price tolerance for natural gas replacing coal in the manufacture of synthetic ammonia can be calculated as $1.42 \mathrm{CNY} / \mathrm{m}^{3}$ when the price of coal is $600 \mathrm{CNY} /$ ton (Table 3.14).

\subsubsection{Price Tolerance of Natural Gas is Very Weak for the Manufacture of Methanol}

Production of methanol in China relies on coal and natural gas as the main raw materials, accounting for 63 and 28\%, respectively. The price of the urea end product is essentially guided by the cost of the coal raw material. Thus, from the perspective of sector development, natural gas has a relationship as a substitute for coal in the manufacture of methanol.

Basing calculations on the principle of equivalent finished product costs, the price tolerance for natural gas replacing coal in the manufacture of methanol can be calculated as $1.71 \mathrm{CNY} / \mathrm{m}^{3}$ when the price of coal is $600 \mathrm{CNY} /$ ton (Table 3.15).

Table 3.14 Natural gas tolerance in production of synthetic ammonia as replacement for coal

\begin{tabular}{|l|l|l|l|l|l|l|}
\hline $\begin{array}{l}\text { Coal } \\
\text { Price } \\
(\mathrm{CNY} / \text { ton })\end{array}$ & $\begin{array}{l}\text { Consumed } \\
\text { amount } \\
(\mathrm{kg} / \mathrm{t})\end{array}$ & $\begin{array}{l}\text { Conversion } \\
\text { cost } \\
(\mathrm{CNY} / \mathrm{ton})\end{array}$ & $\begin{array}{l}\text { Urea finished } \\
\text { product cost } \\
(\mathrm{CNY} / \text { ton })\end{array}$ & $\begin{array}{l}\text { Natural gas } \\
\text { Conversion } \\
\text { cost } \\
(\mathrm{CNY} / \mathrm{ton})\end{array}$ & $\begin{array}{l}\text { Consumed } \\
\text { amount } \\
\left(\mathrm{m}^{3} / \text { ton }\right)\end{array}$ & $\begin{array}{l}\text { Price } \\
\text { tolerance } \\
\left(\mathrm{CNY} / \mathrm{m}^{3}\right)\end{array}$ \\
\hline 800 & 1080 & 1000 & 1738 & 800 & 600 & 1.77 \\
\hline 600 & & 1554 & & & 1.42 \\
\hline 400 & & 1369 & & 1.07 & \\
\hline
\end{tabular}

Data source Results of calculation

Table 3.15 Methanol production price tolerance of natural gas as replacement for coal-based production

\begin{tabular}{|l|l|l|l|l|l|l|}
\hline $\begin{array}{l}\text { Coal } \\
\text { Price } \\
(\mathrm{CNY} / \text { ton })\end{array}$ & $\begin{array}{l}\text { Consumed } \\
\text { amount } \\
(\mathrm{kg} / \mathrm{ton})\end{array}$ & $\begin{array}{l}\text { Conversion } \\
\text { cost } \\
(\mathrm{CNY} / \text { ton })\end{array}$ & $\begin{array}{l}\text { Methanol finished } \\
\text { product cost } \\
\text { (CNY/ton })\end{array}$ & $\begin{array}{l}\text { Natural gas } \\
\text { Conversion } \\
\text { cost } \\
(\mathrm{CNY} / \text { ton })\end{array}$ & $\begin{array}{l}\text { Consumed } \\
\text { amount } \\
\left(\mathrm{m}^{3} / \text { ton }\right)\end{array}$ & $\begin{array}{l}\text { Price } \\
\text { tolerance } \\
\left(\mathrm{CNY} / \mathrm{m}^{3}\right)\end{array}$ \\
\hline 800 & 1400 & 1500 & 2457 & 900 & 870 & 2.02 \\
\hline 600 & & 2218 & & & 1.71 \\
\hline 400 & & & 1979 & & 1.40 \\
\hline
\end{tabular}

Data source Results of calculation 
Table 3.16 Hydrogen production price tolerance of natural gas as replacement for coal-based production

\begin{tabular}{|l|l|l|l|l|l|l|l|}
\hline $\begin{array}{l}\text { International } \\
\text { crude oil } \\
\text { price }(\$ / \mathrm{bbl})\end{array}$ & $\begin{array}{l}\text { Naphtha } \\
\text { Price } \\
(\mathrm{CNY} / \mathrm{kg})\end{array}$ & $\begin{array}{l}\text { Consumed } \\
\text { amount } \\
(\mathrm{kg} / \mathrm{ton})\end{array}$ & $\begin{array}{l}\text { Conversion } \\
\text { cost }(\mathrm{CNY} / \mathrm{ton})\end{array}$ & $\begin{array}{l}\text { Hydrogen } \\
\text { finished } \\
\text { product cost } \\
(\mathrm{CNY} / \mathrm{ton})\end{array}$ & $\begin{array}{l}\text { Natural gas } \\
\text { Conversion } \\
\text { cost } \\
(\mathrm{CNY} / \mathrm{ton})\end{array}$ & $\begin{array}{l}\text { Consumed } \\
\text { amount } \\
\left(\mathrm{m}^{3} / \text { ton }\right)\end{array}$ & $\begin{array}{l}\text { Price } \\
\text { tolerance } \\
\left(\mathrm{CNY} / \mathrm{m}^{3}\right)\end{array}$ \\
\hline 100 & 10.64 & 3600 & 1000 & 33,731 & 650 & 5200 & 7.19 \\
80 & 8.51 & & & 27,185 & & 5.77 \\
60 & 6.38 & & & 20,638 & & 4.34
\end{tabular}

Data source Results of calculation

\subsubsection{Price Tolerance of Natural Gas is Very Strong for the Manufacture of Hydrogen}

Natural gas has a high methane content, and when used as the raw material in the production of hydrogen it results in a high hydrogen yield in addition to reducing fuel consumption, making it the ideal raw material. The majority of the world's hydrogen is manufactured using natural gas as a raw material. However, in China the raw material most used in the manufacture of hydrogen is coal, although petrochemical enterprises manufacture hydrogen using mainly naphtha. Natural gas is primarily used in the manufacture of hydrogen by petrochemical enterprises as an alternative to naphtha. Basing calculations on the principle of equivalent finished product costs, the price tolerance for natural gas replacing naphtha can be calculated as $7.19 \mathrm{CNY} / \mathrm{m}^{3}$ when the international price of crude oil is $100 \$ / \mathrm{bbl}$ and $4.34 \mathrm{CNY} / \mathrm{m}^{3}$ when the international price of crude oil is $60 \$ / \mathrm{bbl}$ (Table 3.16).

\subsection{China's Natural Gas Demand Curve and Ways to Increase Natural Gas Consumption}

\subsubsection{China's Natural Gas Prices in 2013}

\section{Shanghai as the baseline}

In July 2013, the National Development and Reform Commission issued the Notice
Regarding Natural Gas Prices (FGJG 2013, No. 1246), in which a reform plan was proposed for natural gas prices. Considering China's natural gas market resource trends, consumption and management distribution as a whole, Shanghai was chosen as the pricing baseline location. Station prices across the country in all provinces as well as all user terminal natural gas prices were tied to the Shanghai station price.

\section{Individual subsidies for each provincial station}

The price difference between each province's station price and the pricing baseline of the Shanghai station price was the subsidy. The main factor affecting provincial subsidies was transportation cost (Table 3.17).

\section{End price calculations for provincial users}

Provincial station price $=$ Shanghai station price - subsidy

City station price $=$ provincial station price + provincial pipeline network pipeline transport fee

City natural gas user terminal price $=$ city station price + city distribution fee

Large industrial user delivery price $=$ city station price + provincial pipeline network pipeline transport fee

CNG filling sales price $=$ city station price + CNG compression and distribution fee

LNG filling sales price $=$ city station price + LNG liquid filling fee

Depending on the provincial pipeline network pipeline transport fee for each province, the city 
Table 3.17 Station price subsidies in each province

\begin{tabular}{|l|l|l|l|l|l|l|l|l|} 
No. & Province & Subsidy & No. & Province & Subsidy & No. & Province & Subsidy \\
\hline 1 & Shanghai & 0.00 & 11 & Shandong & 0.20 & 21 & Sichuan & 0.53 \\
\hline 2 & Guangdong & 0.00 & 12 & Liaoning & 0.20 & 22 & Chongqing & 0.54 \\
\hline 3 & Zhejiang & 0.01 & 13 & Hubei & 0.22 & 23 & Hainan & 0.54 \\
\hline 4 & Jiangsu & 0.02 & 14 & Jiangxi & 0.22 & 24 & Ningxia & 0.67 \\
\hline 5 & Anhui & 0.09 & 15 & Hunan & 0.22 & 25 & Gansu & 0.75 \\
\hline 6 & Henan & 0.17 & 16 & Shanxi & 0.27 & 26 & Shaanxi & 0.84 \\
\hline 7 & Guangxi & 0.17 & 17 & Heilongiang & 0.42 & 27 & Inner Mongolia & 0.84 \\
\hline 8 & Beijing & 0.18 & 18 & Jilin & 0.42 & 28 & Qinghai & 0.91 \\
\hline 9 & Tianjin & 0.18 & 19 & Yunnan & 0.47 & 29 & Xinjiang & 1.03 \\
\hline 10 & Hebei & 0.20 & 20 & Guizhou & 0.47 & 30 & Tibet & 1.50
\end{tabular}

distribution fee, CNG compression and distribution fee and LNG liquid filling fee, the average values are $0.2,0.75,1.5$ and $2.0 \mathrm{CNY} / \mathrm{m}^{3}$, respectively.

\subsubsection{Natural Gas Demand Curve for China in 2013}

\section{Summary of price tolerance for different users}

Based on the calculations in this chapter, when the international price of crude oil is $80 \$ / \mathrm{bbl}$, and when raw coal price is $600 \mathrm{CNY} /$ ton, the terminal price tolerance for natural gas usage by users in various sectors is $1.4-5.77 \mathrm{CNY} / \mathrm{m}^{3}$. Within this range, the price tolerance is relatively high for residential, commercial services, vehicle and ship transport, and natural gas manufacturing of hydrogen, but relatively low for centralised heating, natural gas power generation, industrial fuels, synthetic ammonia and methanol (Fig. 3.4).

During the optimisation of primary energy consumption structures, for natural gas replacement of oil as the fuel in industrial processes, the natural gas price tolerance is $2.59 \mathrm{CNY} / \mathrm{m}^{3}$, while for natural gas chemicals, the price tolerance of natural gas for use in the production of hydrogen as a replacement for naphtha is highest, with a maximum natural gas price tolerance of $5.77 \mathrm{CNY} / \mathrm{m}^{3}$.

In terms of natural gas as a replacement secondary energy source for electricity in residential and commercial use, natural gas price tolerance ranks only second to natural gas substituting petroleum, at around 3.7 $\mathrm{CNY} / \mathrm{m}^{3}$ (Fig. 3.5).

During the process of natural gas replacing coal, natural gas price tolerance is generally low, and only when it is used as a substitute for syngas is the natural gas price tolerance relatively high at $2.46 \mathrm{CNY} / \mathrm{m}^{3}$. Price tolerance for other coal use, whether for heating, synthetic ammonia, methanol production, steam boilers or power generation, is only around $1.5 \mathrm{CNY} / \mathrm{m}^{3}$.

\section{Construction of the natural gas demand curve}

Step 1: The total consumption of natural gas in China of 166 billion $\mathrm{m}^{3}$ was divided between 30 provinces, 5 categories and 16 types of user.

Step 2: The prices of alternative energies such as coal, fuel oil, naphtha, \#93 petrol, \#0 diesel, LPG, electric power and data on urban residents' disposable income was collated, and an evaluation of the terminal price tolerance of 16 kinds of natural gas user carried out.

Step 3: Terminal price tolerance of natural gas users was normalised using natural gas pricing mechanisms based on the Shanghai natural gas benchmark price.

Step 4: The tolerance for the Shanghai benchmark price of the 30 provinces, 5 categories and 16 types of user was organised from high to low, yielding the effective China natural gas market demand curve. 


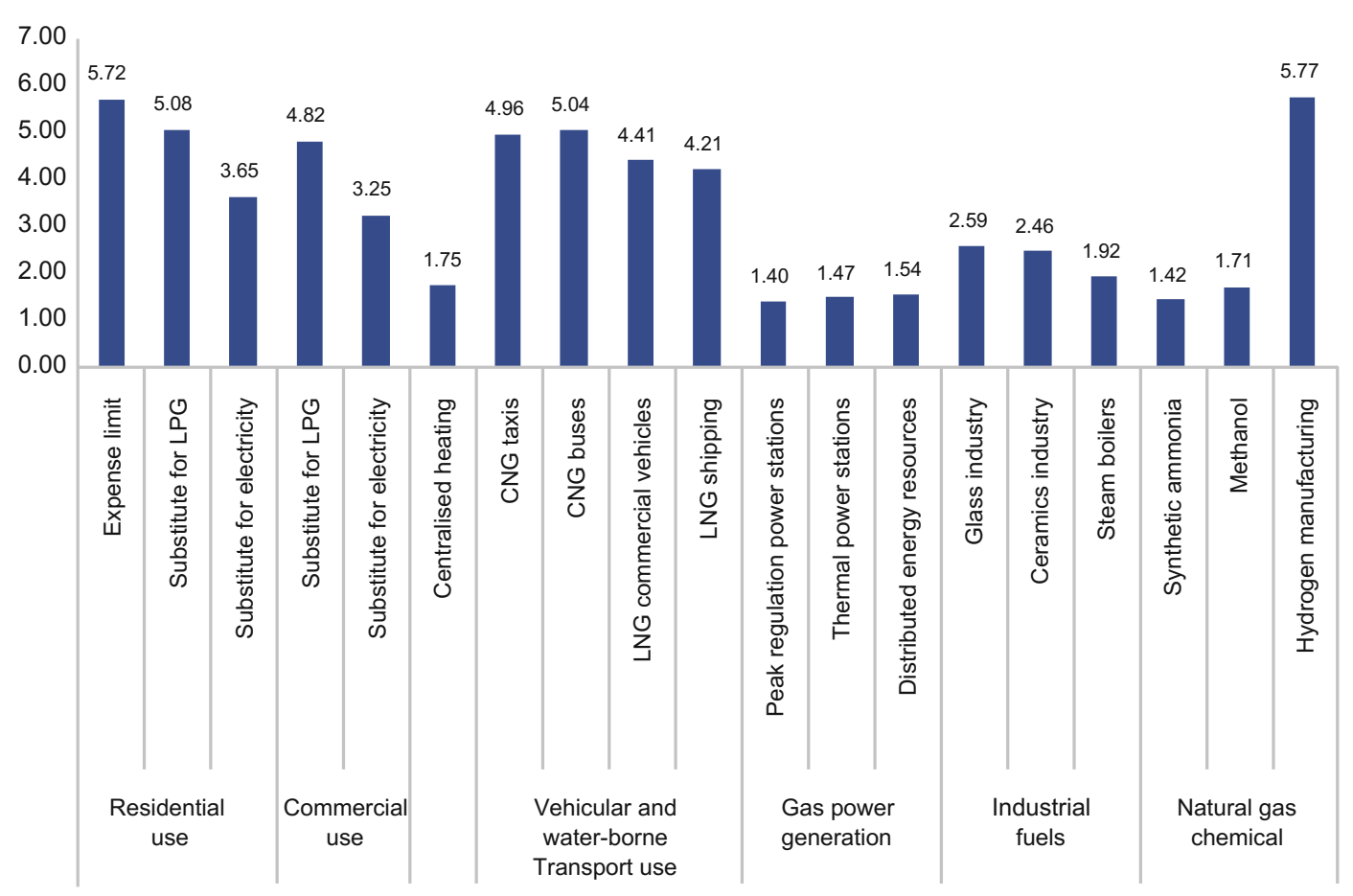

Fig. 3.4 Terminal price tolerance for users in various natural gas sectors

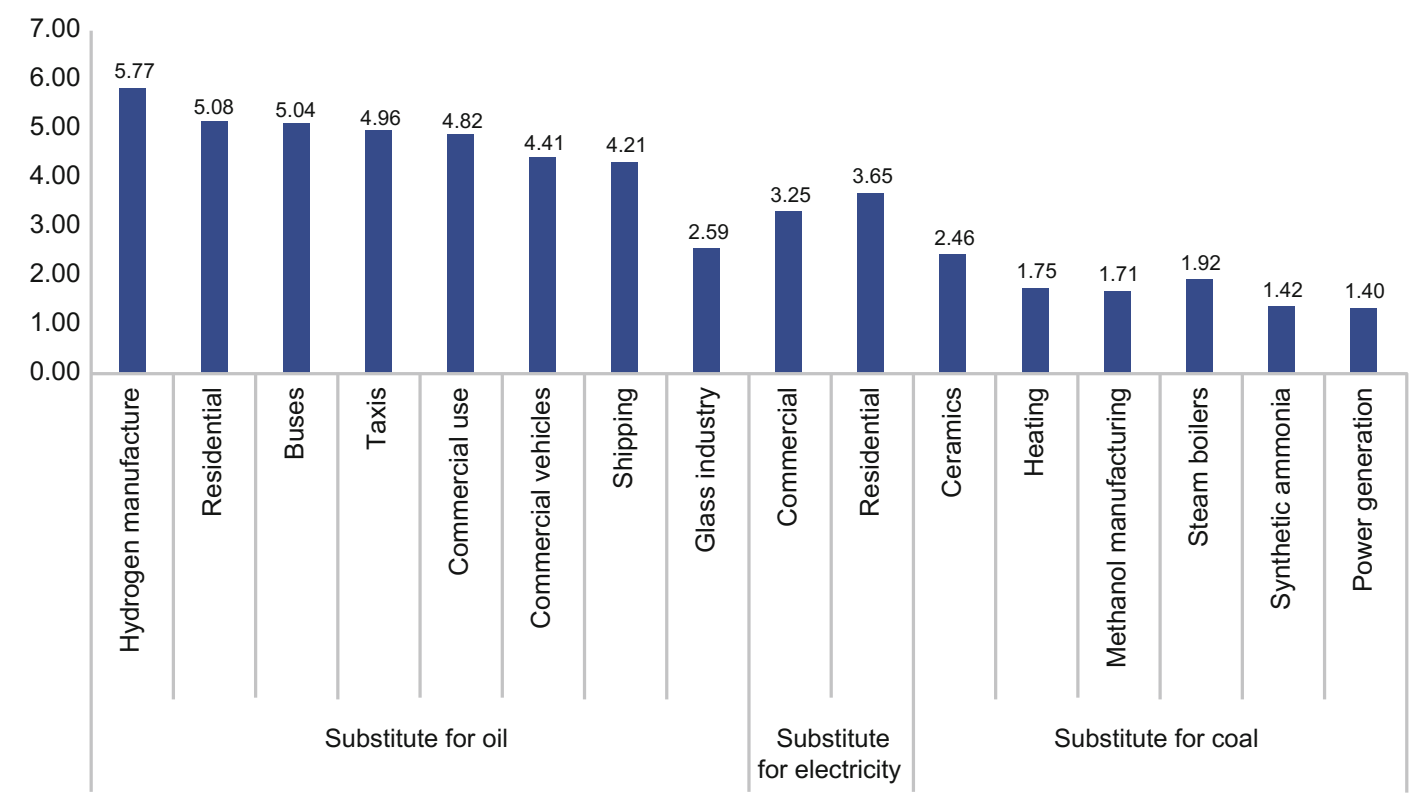

Fig. 3.5 Terminal price tolerance of main gas market users in terms of energy substitution 


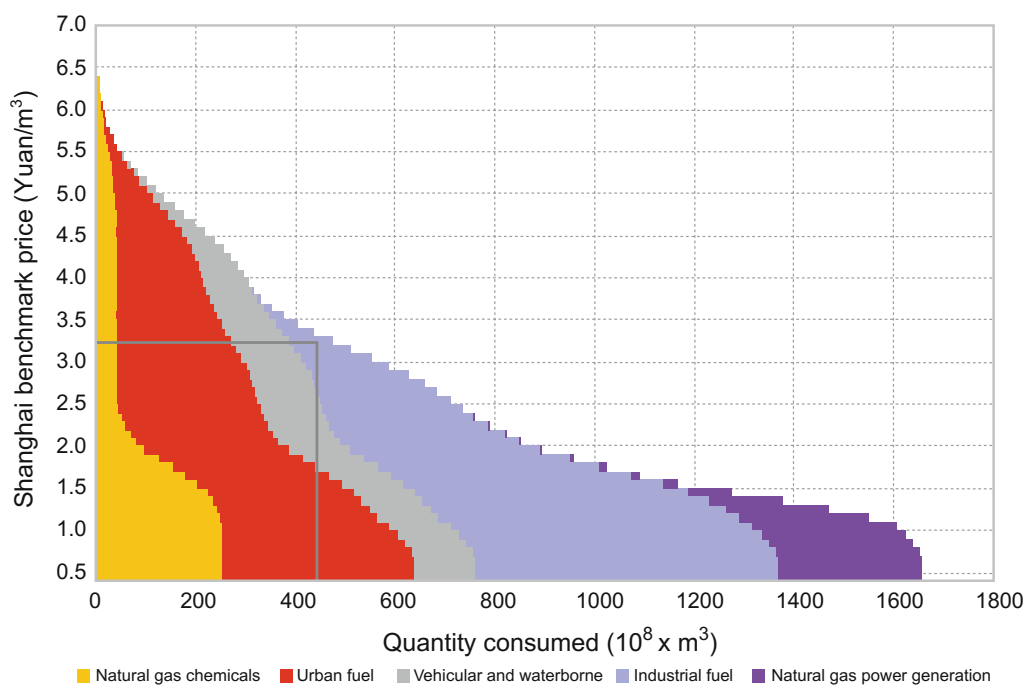

Fig. 3.6 Effective 2013 China natural gas market demand curve

This finally yielded the 2013 China natural gas demand curve, as shown in Fig. 3.6.

\subsubsection{Implementation Model of Effective Demand and Actual Natural Gas Consumption Based on Natural Gas Price Reform Targets}

In 2013, China proposed a natural gas price reform scheme, which set the Shanghai benchmark price of natural gas at $3.32 \mathrm{CNY} / \mathrm{m}^{3}$. From the effective demand curve of the natural gas market it can be seen that, in 2013, China's actual consumption of natural gas reached 167.6 billion $\mathrm{m}^{3}$, and, based on the Shanghai benchmark price of $3.32 \mathrm{CNY} / \mathrm{m}^{3}$, the corresponding effective demand reaches 50 billion $\mathrm{m}^{3}$, which only accounts for $30 \%$ of actual consumption. The natural gas consumption in urban centralised heating, power generation, ammonia and methanol synthesis and for most industrial fuels cannot be the effective demand based on the Shanghai benchmark price of $3.32 \mathrm{CNY} / \mathrm{m}^{3}$ (Table 3.18).

In 2013, China's actual natural gas consumption reached 166 billion $\mathrm{m}^{3}$, which substantially exceeds the effective demand calculated based on price tolerance, being a result of various natural gas supportive policies.
1. Natural gas price reform transitional policy-gas suppliers providing subsidies of nearly 150 billion CNY to users

The natural gas price reform scheme implemented by the state specified that the civil natural gas price would not be changed, the fertiliser natural gas price would be slightly adjusted, and non-residential use natural gas prices would have a stored gas and reserve gas two-tier system applied to them. During the natural gas price reform transitional period, an unsatisfactory low price policy was applied to natural gas, with natural gas suppliers providing subsidies to natural gas consumer enterprises to ensure that users could afford gas and that natural gas consumption reached a certain level.

In 2013, the national average urban resident terminal natural gas price was $2.15 \mathrm{CNY} / \mathrm{m}^{3}$ and the average resident natural gas provincial gate price was $1.37 \mathrm{CNY} / \mathrm{m}^{3}$, which was $1.50 \mathrm{CNY} / \mathrm{m}^{3}$ lower than the average national incremental natural gas price. Natural gas suppliers granted around 27 billion CNY of subsidies to urban residential users based on a residential natural gas consumption of 18 billion $\mathrm{m}^{3}$.

The average fertiliser natural gas consumption price was adjusted slightly to around $1.80 \mathrm{CNY} / \mathrm{m}^{3}$, being $1.10 \mathrm{CNY} / \mathrm{m}^{3}$ lower than the average national incremental natural gas price. 
Table 3.18 Effective demand of natural gas in China based on the Shanghai benchmark price in 2013

\begin{tabular}{|c|c|c|c|c|c|c|}
\hline \multirow[t]{2}{*}{ Main purpose } & & \multicolumn{2}{|c|}{ Actual consumption } & \multicolumn{2}{|c|}{ Effective demand } & \multirow{2}{*}{$\begin{array}{l}\text { Growth } \\
\text { rate }(\%)\end{array}$} \\
\hline & & Quantity & Proportion (\%) & Consumption & Proportion $(\%)$ & \\
\hline \multirow[t]{3}{*}{ Urban fuel gas } & Residential & 181 & 10.95 & 147 & 30.95 & 81 \\
\hline & $\begin{array}{l}\text { Commercial } \\
\text { service }\end{array}$ & 104 & 6.29 & 84 & 17.61 & 80 \\
\hline & Centralised heating & 97 & 5.87 & & & \\
\hline \multirow{4}{*}{$\begin{array}{l}\text { Vehicular and } \\
\text { waterborne } \\
\text { transportation }\end{array}$} & CNG taxi & 59 & 3.57 & 59 & 12.43 & 100 \\
\hline & CNG bus & 32 & 1.94 & 32 & 6.74 & 100 \\
\hline & LNG lorry & 33 & 2.00 & 24 & 4.96 & 71 \\
\hline & LNG shipping & & & & & \\
\hline \multirow[t]{3}{*}{$\begin{array}{l}\text { Gas-fired power } \\
\text { generation }\end{array}$} & $\begin{array}{l}\text { Peak-load } \\
\text { regulation power } \\
\text { plant }\end{array}$ & 157 & 9.50 & & & \\
\hline & $\begin{array}{l}\text { Thermal power } \\
\text { plant }\end{array}$ & 126 & 7.62 & & & \\
\hline & $\begin{array}{l}\text { Distributed energy } \\
\text { resources }\end{array}$ & 4 & 0.24 & & & \\
\hline Industrial fuels & & 606 & 36.66 & 88 & 17.45 & 15 \\
\hline \multirow{3}{*}{$\begin{array}{l}\text { Natural gas } \\
\text { chemical industry }\end{array}$} & Synthetic ammonia & 152 & 9.20 & & & \\
\hline & Methanol & 61 & 3.69 & & & \\
\hline & $\begin{array}{l}\text { Hydrogen } \\
\text { production, etc. }\end{array}$ & 41 & 2.48 & 41 & 8.28 & 100 \\
\hline Total & & 1653 & 100 & 475 & 100 & 29 \\
\hline
\end{tabular}

Data source Calculation results

(Units of 100 million $\mathrm{m}^{3}$ )

Natural gas suppliers granted around 22 billion CNY of subsidies to fertiliser users based on a fertiliser natural gas consumption of 20 billion $\mathrm{m}^{3}$.

In 2013, the stored natural gas price in various provinces in China was $0.88 \mathrm{CNY} / \mathrm{m}^{3}$ lower than the incremental natural gas. Natural gas suppliers subsidised non-residential stored natural gas users to the tune of around 100 billion CNY based on a non-residential stored natural gas volume of 110 billion $\mathrm{m}^{3}$.

\section{Special pricing policy for natural gas gen- eration electricity prices}

The Notice on Relevant Matters for Adjusting Grid Purchase Price of Power Generation Enterprises issued by the National Development and Reform Commission on September 30, 2013, besides reducing the desulphurised coal power electricity grid price for all provinces (regions and cities), required that the gas-fired power electricity grid price in provinces (regions and cities) such as Shanghai, Jiangsu, Zhejiang, Guangdong, Hainan, Henan, Hubei and Ningxia should be increased, thus easing slightly the conflicting influences on the natural gas price. In China, the grid price of gas power electricity is $40 \%$ higher than that of coal power electricity (around $0.20 \mathrm{CNY} / \mathrm{kWh}$ ). Based on 28.5 billion $\mathrm{m}^{3}$ residential natural gas consumption, around 570 million CNY of the cost of gas generated electricity is transferred from power suppliers to the user.

\section{Supportive policy for natural gas use}

Generous fiscal subsidies are granted in many locations to encourage the adoption of natural 
gas centralised heating. Compared with coal-fired centralised heating, the natural gas price tolerance for gas-fired centralised heating only reached $1.75 \mathrm{CNY} / \mathrm{m}^{3}$. After deducting urban natural gas distribution costs, the provincial gate natural gas price tolerance reached around $1.00 \mathrm{CNY} / \mathrm{m}^{3}$. If the unit price charged for centralised heating is not adjusted, the economic benefits of gas-fired centralised heating would be almost the same as those of coal-fired central heating. Based on the stored natural gas price of $2.2 \mathrm{CNY} / \mathrm{m}^{3}$ and a heating natural gas consumption of 10 billion $\mathrm{m}^{3}$, the fiscal subsidy granted by local government for gas-fired centralised heating reached around CNY 12 billion.

\section{Coercive policy for natural gas use}

In September 2013, the State Council published the Action Plan for Atmospheric Contamination Prevention, which requires the acceleration of coal to gas conversions, with the aim of eliminating small urban coal-fired boilers, establishing coal-free zones etc. to speed up the adoption of natural gas in heating boilers, industrial boilers and thermoelectric projects. Cities at all levels were required to rid themselves of coal-fired boilers with capacity less than 10 tons of steam per hour, and the construction of coal-fired boilers with capacity of 20 tons of steam or less per hour was forbidden. Most industrial fuel users have a low tolerance for natural gas prices, but based on policy requirements, they are now required to absorb the costs of natural gas themselves.

Judging from the natural gas effective demand curve, the demand for stored natural gas that could be supported by industrial fuel users reached 30 billion $\mathrm{m}^{3}$, while the increased cost of CNY 27 billion associated with the other 30 billion $\mathrm{m}^{3}$ of industrial fuel consumption had to be absorbed by the enterprises themselves, posing challenges for the sustainable development of natural gas-consuming enterprises.
Open Access This chapter is licensed under the terms of the Creative Commons Attribution 4.0 International License (http://creativecommons.org/licenses/by/4.0/), which permits use, sharing, adaptation, distribution and reproduction in any medium or format, as long as you give appropriate credit to the original author(s) and the source, provide a link to the Creative Commons license and indicate if changes were made.
The images or other third party material in this chapter are included in the chapter's Creative Commons license, unless indicated otherwise in a credit line to the material. If material is not included in the chapter's Creative Commons license and your intended use is not permitted by statutory regulation or exceeds the permitted use, you will need to obtain permission directly from the copyright holder. 